\title{
Left Ventricular Hypertrophy in Chronic Bronchitis
}

\author{
D. C. FLUCK ${ }^{\star}$, R. G. CHANDRASEKAR, AND F. V. GARDNER \\ From the Department of Cardiology, Royal Free Hospital, London W.C.1
}

Cor pulmonale is widely accepted as being solely due to strain on the right ventricle, though left ventricular hypertrophy has been reported as occurring in chronic pulmonary disease (Altschule, 1962). In view of this, it was decided to carry out a retrospective post-mortem study to try to establish whether left ventricular hypertrophy does occur in chronic bronchitis in the absence of a specific cause.

\section{Patients AND Method}

The post-mortem records of patients who had died between 1954 and 1963 at the Royal Free Hospital were examined, and all those with the diagnosis of chronic bronchitis were selected for further study.

Their clinical records were analysed for (1) a history of chronic bronchitis; and (2) blood pressure reading.

Their post-mortem reports were analysed for (1) thickness of the right and left ventricular walls; (2) evidence of ischaemic heart disease; (3) presence of significant nephrosclerosis; (4) evidence of chronic bronchitis and other chronic pulmonary diseases; and (5) presence of any other conditions known to cause left ventricular disease.

A number of patients with chronic bronchitis had minor degrees of bronchiectasis and a few had an associated bronchial neoplasm.

The upper limit of normal for the right and left ventricular wall thickness in the Royal Free Pathology Department is accepted as $5 \mathrm{~mm}$. and $15 \mathrm{~mm}$., respectively. The pathologists who made these ventricular wall thickness measurements were unaware of any interest in showing the occurrence of left ventricular hypertrophy in chronic bronchitis.

The upper limit of normal blood pressure was taken to be $150 / 95 \mathrm{~mm}$. Hg. If there was one reading above this level the patient was considered to have systemic hypertension.

Those with left ventricular hypertrophy were included only if systemic hypertension, ischaemic heart disease, significant nephrosclerosis, or any other condition known to cause left ventricular hypertrophy were absent.

Received March 1, 1965.

* Present address: Cardiovascular Research Unit, Hammersmith Hospital, London W.12.
A series of control patients who had no chronic pulmonary disease were studied in a similar way.

\section{RESULTS}

The distribution of the left ventricular wall thickness, according to age and sex, for the chronic bronchitics and controls is shown in Fig. 1 and 2. Similarly, the distribution of the right ventricular wall thickness is shown in Fig. 3 and 4.

Unfortunately, the chronic bronchitics and control patients were not balanced for sex, but there are only small non-significant differences between the mean left ventricular wall thickness of the males and females, both in the chronic bronchitics and in the controls. This is also true of the mean right ventricular wall thickness (Table I).

Although the mean ages of the chronic bronchitics and controls differed by less than 2 years (being 65.0 years and 63.7 years, respectively), the age distribution was slightly different. However, there was no correlation between left ventricular and right ventricular wall thickness with age, in either the chronic bronchitic or control cases (Fig. 1, 2, 3, and 4).

Of the 84 chronic bronchitics, 31 had a left ventricular wall thickness of $16 \mathrm{~mm}$. or more. In these 31, 7 had had their blood pressure recorded for 3 years or more, 5 for more than 1 year but less than 3 years, and the other 19 had had at least one blood pressure recorded when the patient was not acutely ill. An unusually large number of cases both in the chronic bronchitics and controls had a left ventricular wall thickness of $15 \mathrm{~mm}$. This was probably because the pathologist who measured the ventricular wall thickness was unconsciously biased by the accepted upper limit of normal for left ventricular wall thickness being $15 \mathrm{~mm}$. In order to eliminate this error, the incidence of cases with left ventricular wall thickness of $17 \mathrm{~mm}$. or more in the chronic bronchitics and controls was compared 92 


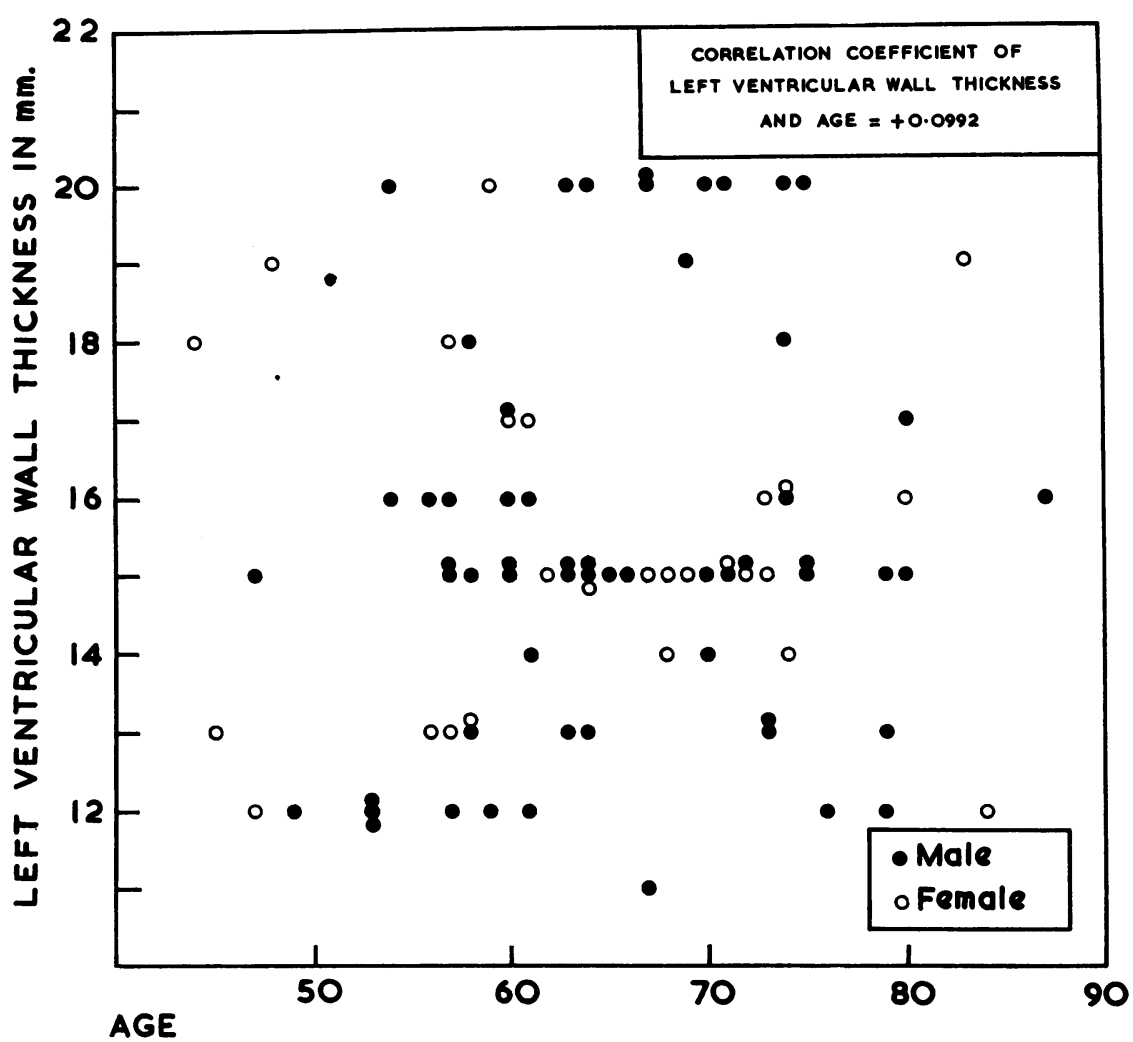

FIG. 1.-The distribution of the left ventricular wall thickness in the chronic bronchitic cases.

TABLE I

MEAN LEFT VENTRICULAR AND RIGHT VENTRICULAR WALL THICKNESS IN CHRONIC BRONCHITIC AND CONTROL CASES

\begin{tabular}{|c|c|c|c|c|c|c|c|c|c|c|c|c|}
\hline & \multicolumn{6}{|c|}{$\begin{array}{c}\text { Left ventricular } \\
\text { wall thickness }(\mathrm{mm} .)\end{array}$} & \multicolumn{6}{|c|}{$\begin{array}{l}\text { Right ventricular } \\
\text { wall thickness (mm.) }\end{array}$} \\
\hline & \multicolumn{3}{|c|}{ Chronic bronchitics } & \multicolumn{3}{|c|}{ Controls } & \multicolumn{3}{|c|}{ Chronic bronchitics } & \multicolumn{3}{|c|}{ Controls } \\
\hline & $\mathbf{M}$ & F & $\underset{\mathrm{F}}{\mathrm{M}}$ & $\mathbf{M}$ & F & $\underset{\mathrm{F}}{\mathrm{M}}$ & $\mathbf{M}$ & $\mathbf{F}$ & $\underset{\mathbf{F}}{\mathbf{M}}$ & $M$ & $\mathbf{F}$ & $\underset{\mathbf{F}}{\mathbf{M}}$ \\
\hline \begin{tabular}{lll} 
Mean & \multicolumn{2}{c}{..} \\
Standard deviation \\
No. $\quad . . \quad \ldots$
\end{tabular} & $\begin{array}{l}15 \cdot 36 \\
\pm 2 \cdot 60 \\
58\end{array}$ & $\begin{array}{l}15 \cdot 38 \\
\pm 2 \cdot 14 \\
26\end{array}$ & $\begin{array}{l}15 \cdot 37 \\
\pm 2 \cdot 46 \\
84\end{array}$ & $\begin{array}{l}14.09 \\
+2.50 \\
33\end{array}$ & $\begin{array}{l}14 \cdot 28 \\
\pm 2 \cdot 25 \\
50\end{array}$ & $\begin{array}{r}14 \cdot 20 \\
\pm 2 \cdot 35 \\
83\end{array}$ & $\begin{array}{r}6.57 \\
+2.51 \\
58\end{array}$ & $\begin{array}{r}5 \cdot 93 \\
+2 \cdot 59 \\
26\end{array}$ & $\begin{aligned} & 6 \cdot 37 \\
& \pm 2 \cdot 56 \\
& 84\end{aligned}$ & $\begin{array}{l}4 \cdot 15 \\
+1 \cdot 10 \\
33\end{array}$ & $\begin{array}{r}4 \cdot 18 \\
+0.97 \\
50\end{array}$ & $\begin{array}{r}4 \cdot 17 \\
\pm 1 \cdot 03 \\
83\end{array}$ \\
\hline
\end{tabular}

TABLE II

INCIDENCE OF CASES WITH LEFT VENTRICULAR WALL THICKNESS $\geqslant 17 \mathrm{~mm}$. IN CHRONIC BRONCHITIC AND CONTROL CASES

\begin{tabular}{|c|c|c|c|c|c|c|c|c|}
\hline \multirow{2}{*}{\multicolumn{2}{|c|}{$\begin{array}{l}\text { Left ventricular } \\
\text { wall thickness (mm.) }\end{array}$}} & & \multicolumn{2}{|c|}{ Men and women } & \multicolumn{2}{|c|}{ Men } & \multicolumn{2}{|c|}{ Women } \\
\hline & & & $\begin{array}{c}\text { Chronic } \\
\text { bronchitics }\end{array}$ & Controls & $\begin{array}{c}\text { Chronic } \\
\text { bronchitics }\end{array}$ & Controls & $\begin{array}{l}\text { Chronic } \\
\text { bronchitics }\end{array}$ & Controls \\
\hline \multirow[t]{2}{*}{$\begin{array}{l}\leqslant 16 \\
\geqslant 17 \\
\text { Total }\end{array}$} & . & . & $\begin{array}{l}63 \\
21 \\
84\end{array}$ & $\begin{array}{r}77 \\
6 \\
83\end{array}$ & $\begin{array}{l}44 \\
14 \\
58\end{array}$ & $\begin{array}{r}32 \\
1 \\
33\end{array}$ & $\begin{array}{r}19 \\
7 \\
26\end{array}$ & $\begin{array}{r}45 \\
5 \\
50\end{array}$ \\
\hline & & & $\begin{array}{l}x^{2}=8.37 \\
p<0.01\end{array}$ & & $\begin{array}{l}\chi^{2}=5.36 \\
p<0.05\end{array}$ & & $\begin{array}{l}2=2 \cdot 52 \\
\text { Jot significan }\end{array}$ & \\
\hline
\end{tabular}




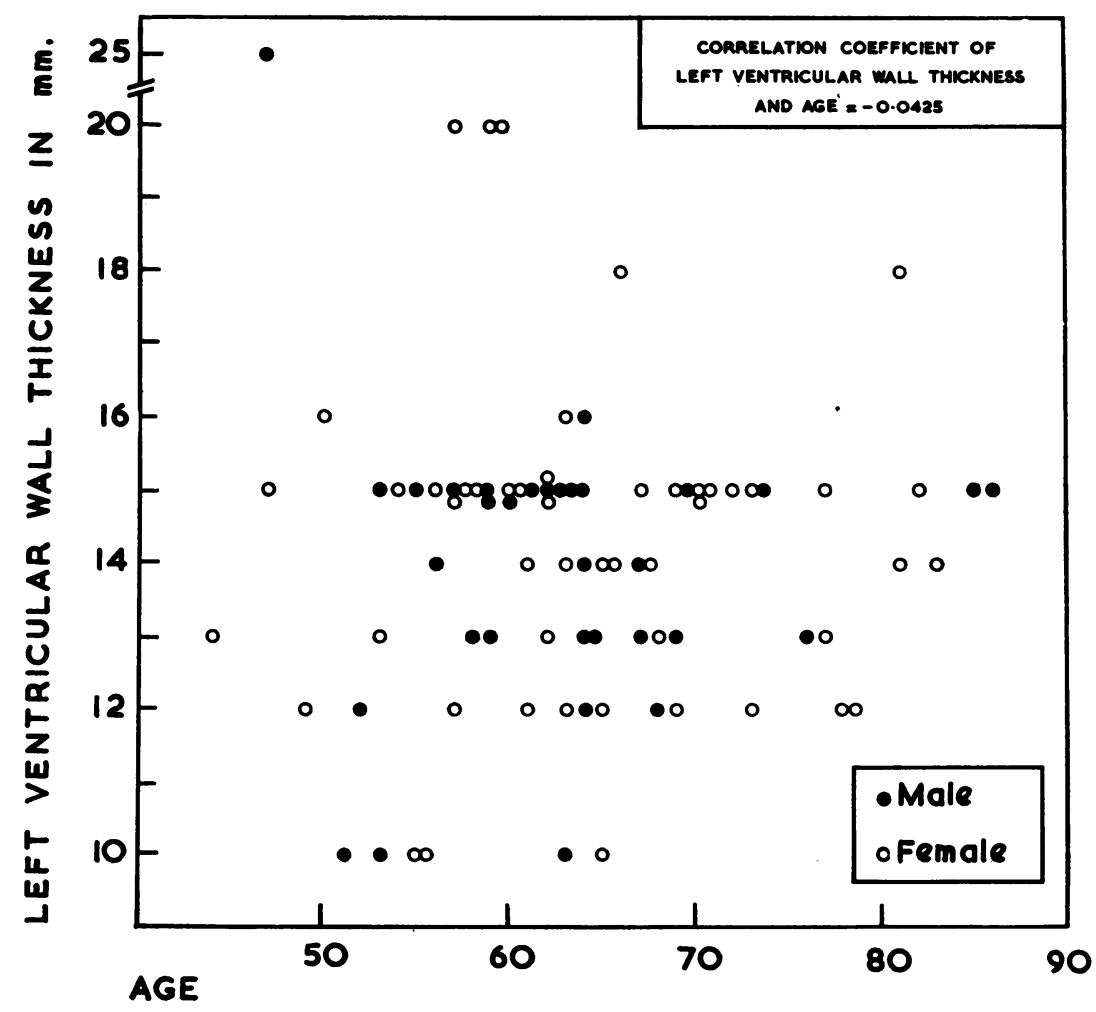

Fig. 2.-The distribution of the left ventricular wall thickness in the control cases.

chronic bronchitics was found for the total $(p<0.01)$ males $(p<0.05)$ but not the females. Of the chronic bronchitics, 25 per cent had left ventricular wall thickness of $17 \mathrm{~mm}$. or more, compared with only 7 per cent in the controls.

The mean left ventricular wall thickness in the chronic bronchitics was 8 per cent more than in the controls, whereas the mean right ventricular wall thickness was 53 per cent more. Thus in chronic bronchitis, though there is a significant incidence of increased left ventricular wall thickness, it is of course the right ventricle that is mainly involved.

\section{Discussion}

When the left ventricle is assessed clinically, unexplained left ventricular hypertrophy in chronic pulmonary disease is uncommon (Parkinson and Hoyle, 1937; Armen, Kantor, and Weiser, 1958). This is probably because the clinical diagnosis of left ventricular hypertrophy in the presence of right ventricular hypertrophy is difficult even with the aid of radiographs and electrocardiographs. However, its incidence at necropsy has been found to be high. Spain and Handler (1946) found it in a number of patients with cor pulmonale, Parker
(1940) found it in about 30 per cent of cases, Kountz, Alexander, and Prinzmetal (1936) in about 60 per cent, and Scott and Garvin (1941), Zimmerman and Ryan (1951), and Michelson (1960) all found it in over 90 per cent of their cases. The differences in incidence found by the previous workers probably reflect differences both in the criteria for the selection of cases and also of assessing the left ventricular hypertrophy. Unfortunately, the results in the previous studies were not compared with controls, but the present study does confirm that there is an appreciable incidence of left ventricular hypertrophy in cases with chronic bronchitis.

Parker (1940) considered that left ventricular hypertrophy was due to undetected systemic hypertension, but in the present study, hypertension has been eliminated as a cause. Others (Kountz et al., 1936; Spain and Handler, 1946) have suggested that it is due to anoxia, and Vacek (1926) has shown that cardiac hypertrophy occurs in mice living under hypoxic conditions.

Increased broncho-pulmonary shunting causing an increased output of the left ventricle has been suggested as a cause of the left ventricular hyper- 


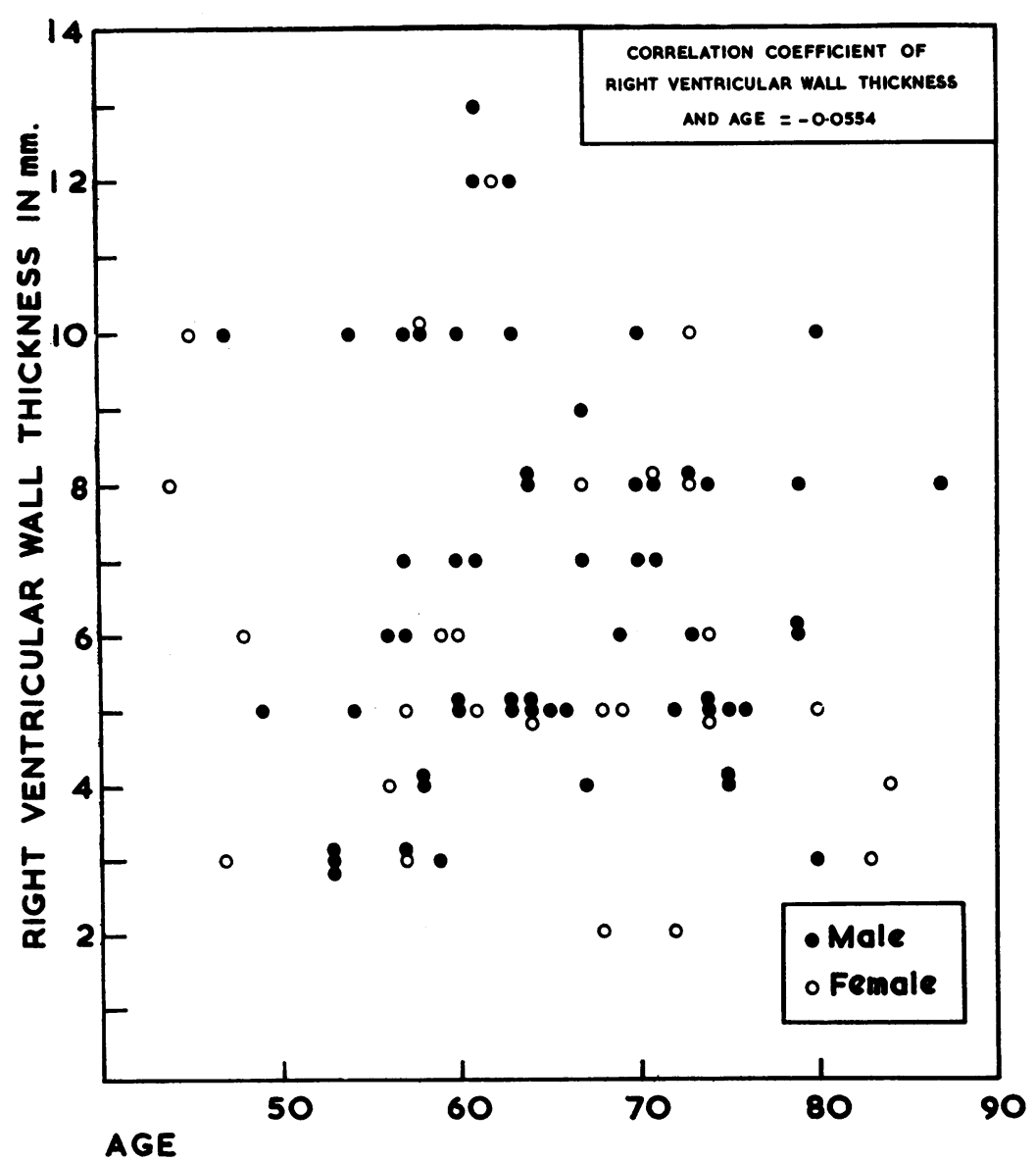

FIG. 3. - The distribution of the right ventricular wall thickness in the chronic bronchitic cases.

trophy (Armen et al., 1958; Cherniack and Cherniack, 1961; Liebow et al., 1950), and increased broncho-pulmonary shunts have been demonstrated both anatomically and physiologically in various pulmonary diseases (Liebow et al., 1950; Cudkowicz and Armstrong, 1953; Turner-Warwick, 1963; Marchand, Gilroy, and Wilson, 1950; Nakamura et al., 1961; Fritts et al., 1961; Gray, Lurie, and Whittemore, 1951; Liebow, Hales, and Lindskog 1949; Roosenburg and Deenstra, 1954; Fishman et al., 1958).

Scott and Garvin (1941) have suggested that the two ventricles are so intimately related that hypertrophy of one ventricle will eventually involve the other, and they consider that hypertrophy of the left ventricle in cor pulmonale is secondary to that of the right.

The cardiac output has been found to be increased in chronic pulmonary disease (Howarth, McMichael, and Sharpey-Schafer, 1947; McMichael and Sharpey-Schafer, 1944; Harvey et al., 1951). This would increase the work of the left ventricle and so explain the left ventricular hypertrophy. However, Wade and Bishop (1962) in an extensive analysis of their own and other published work found the mean cardiac output normal in emphysema at all stages of the disease, though in about 8 per cent of patients the cardiac output was abnormally high.

Hence it appears that there are several possible causes for the unexplained left ventricular hypertrophy in chronic bronchitis, but further studies are required to prove its exact mode of production.

\section{SUMMARY}

In a retrospective post-mortem study 25 per cent of patients with chronic bronchitis were found to have an unexplained increase in left ventricular wall 


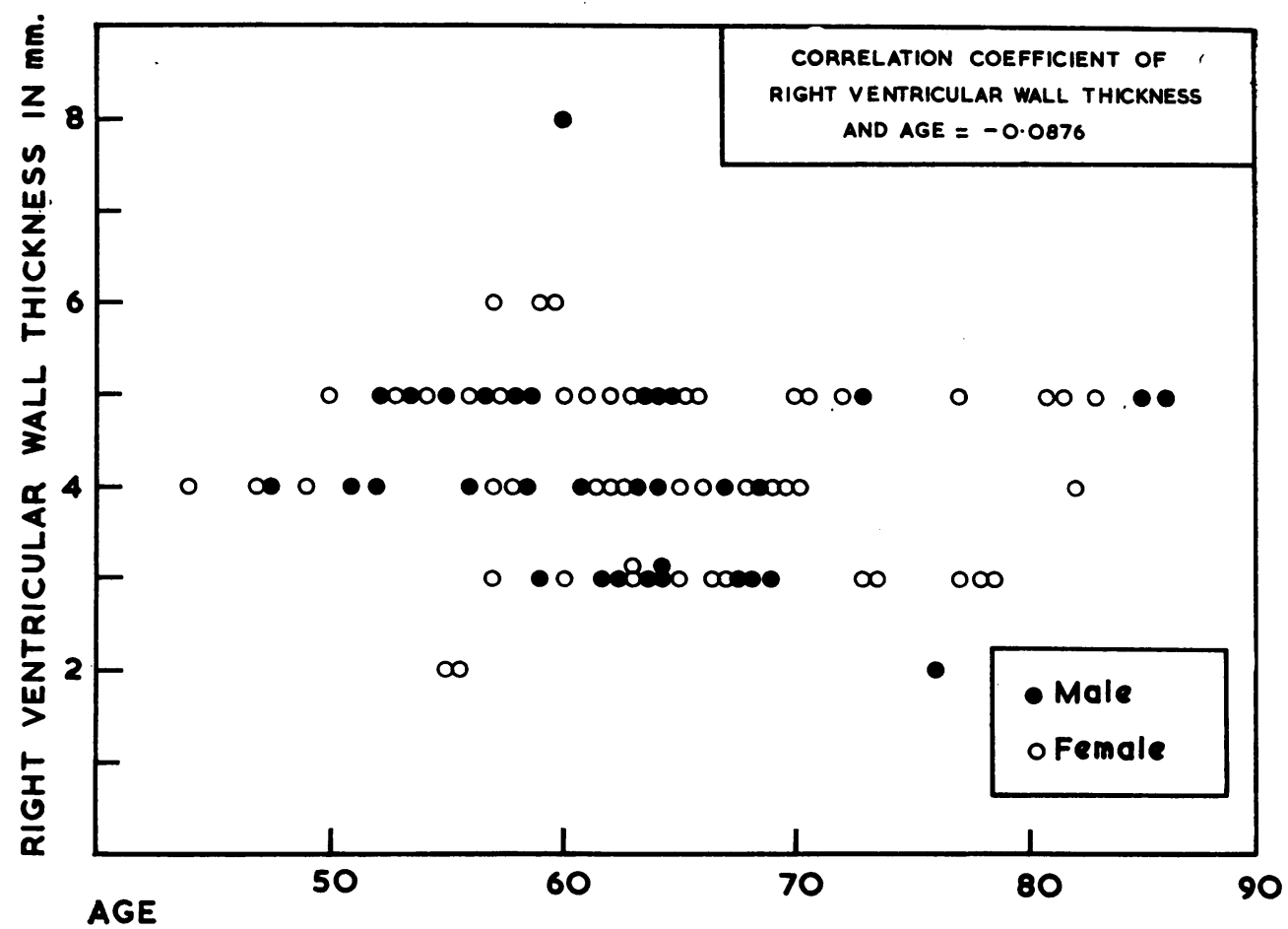

Fig. 4.-The distribution of the right ventricular wall thickness in the control cases.

thickness to $17 \mathrm{~mm}$. or more compared with only 7 per cent of the controls. This difference was significant $(p<0.01)$.

The possible factors that might produce this left ventricular hypertrophy have been discussed.

We wish to thank Professor K. R. Hill for allowing us to study post-mortem records, Dr. W. B. Obank for reviewing the myocardial and renal sections, and $\mathrm{Mr}$. N. W. Please for his advice on the statistics.

\section{REFERENCES}

Altschule, M. D. (1962). Cor pulmonale: A disease of the whole heart. Dis. Chest, 41, 398.

Armen, R. N., Kantor, M., and Weiser, N. J. (1958). Pulmonary heart disease, with emphasis on electrocardiographic diagnosis. Circulation, 17, 164.

Cherniack, R. M., and Cherniack, L. (1961). Respiration in Health and Disease, p. 212. Saunders, Philadelphia.

Cudkowicz, L., and Armstrong, J. B. (1953). The bronchial arteries in pulmonary emphysema. Thorax, 8, 46.

Fishman, A. P., Turino, G. M., Brandfonbrener, M., and Himmelstein, A. (1958). The "effective" pulmonary collateral blood flow in man. $\mathcal{F}$. clin. Invest., 37, 1071.

Fritts, H. W., Jr., Harris, P., Chidsey, C. A., 111, Clauss, R. H., and Cournand, A. (1961). Estimation of flow through bronchial-pulmonary vascular anastomoses with the use of T-1824 dye. Circulation, 23, 390.

Gray, F. D., Jr., Lurie, P. R., and Whittemore, R. (1951). Circulatory changes in chronic pulmonary disease. A study of pulmonary collateral circulation. Yale $\mathfrak{f}$. Biol. Med., 23, 380.

Harvey, R. M., Ferrer, M. I., Richards, D. W., Jr., and Cournand, A. (1951). Influence of chronic pulmonary disease on the heart and circulation. Amer. $\mathcal{F} . M e d ., 10$, 719.

Howarth, S., McMichael, J., and Sharpey-Schafer, E. P. (1947). Effects of oxygen, venesection and digitalis in chronic heart failure from disease of the lungs. Clin. Sci., 6, 187.

Kountz, W. B., Alexander, H. L., and Prinzmetal, M. (1936). The heart in emphysema. Amer. Heart F., 11, 163.

Liebow, A. A., Hales, M. R., Harrison, W., Bloomer, W., and Lindskog, G. E. (1950). The genesis and functional implications of collateral circulation of the lungs. Yale F. Biol. Med., 22, 637.

,-- , and Lindskog, G. E. (1949). Enlargement of the bronchial arteries, and their anastomoses with the pulmonary arteries in bronchiectasis. Amer. F. Path., 25, 211.

Marchand, P., Gilroy, J. C., and Wilson, V. H. (1950). An anatomical study of the bronchial vascular system and its variations in disease. Thorax, 5, 207.

McMichael, J., and Sharpey-Schafer, E. P. (1944). The action of intravenous digoxin in man. Quart. F. Med., n.s. 13, 123.

Michelson, N. (1960). Bilateral ventricular hypertrophy due to chronic pulmonary disease. Dis. Chest, 38, 435.

Nakamura, T., Karoti, R., Miyazawa, K., Ohtomo, S., Watanabe, Ta., Watanabe, Te., Miura, Y., and Takizawa, T. (1961). Bronchial blood flow in patients with chronic pulmonary disease and its influence upon respiration and circulation. Dis. Chest, 39, 192. 
Parker, R. L. (1940). Pulmonary emphysema: A study of its relation to the heart and pulmonary arterial system. Ann. intern. Med., 14, 795.

Parkinson, J., and Hoyle, C. (1937). The heart in emphysema. Quart. F. Med., 30 (n.s. 6), 59.

Roosenburg, J. G., and Deenstra, H. (1954). Bronchialpulmonary vascular shunts in chronic pulmonary affections. Dis. Chest, 26, 664.

Scott, R. W., and Garvin, C. F. (1941). Cor pulmonale: Observations in 50 autopsy cases. Amer. Heart f., 22, 56.

Spain, D. M., and Handler, B. J. (1946). Chronic cor pul- monale. Sixty cases studied at necropsy. Arch. intern. Med., 77, 37.

Turner-Warwick, M. (1963). Precapillary systemic-pulmonary anastomoses. Thorax, 18, 225.

Vacek, T. (1926). Untersuchungen über die funktionelle Adaptation des Herzens bei den im Sauer-stoffmangel lebenden Mäusen. Pflügers Arch. ges. Physiol., 212, 357.

Wade, O. L., and Bishop, J. M. (1962). Cardiac Output and Regional Blood Flow, p. 149. Blackwell, Oxford.

Zimmerman, H. A., and Ryan, J. M. (1951). Cor pulmonale. Dis. Chest, 20, 286. 